\title{
THE PROBLEM OF ALCOHOL CONSUMPTION IN LVIV IN THE SOCIOLOGICAL DIMENSION (BY THE MATERIALS OF THE EMPIRICAL RESEARCH)
}

Halyna Herasym, Olha Herus, Larysa Klymanska, Viktor Savka, Janusz Sieroslawski

Lviv Polytechnic National University, Lviv, Ukraine, Institute of Psychiatry and Neurology, Warsaw, Poland

\section{Abstract.}

Introduction. The article was written on the basis of a sociological study of alcohol consumption conducted in the spring of 2019 in Lviv.

Purpose. The purpose of the article is to provide an overview of the conducted research, focusing mainly on patterns of alcohol consumption and awareness of harm from the residents of Lviv region.

Design/Methodology Approach. A quantitative representative sociological survey with a multi-stage proportional stratification sample and a quota at the last stage. The sample size is 1200 people; Lviv - 400 people, Lviv region - 800 people. The study was conducted according to the methodology and using the toolkit of European questionnaires adapted to the Ukrainian conditions, implemented in 2016-2017. (RARHA 2017).

Results. This research has demonstrated the scale of the problems related to alcohol in Lviv. The results obtained indicate the prevalence of the so-called incidental model of alcohol consumption, which at low frequency of drinking implies a high level of its single consumption. Alcoholic beverages are predominant in the structure of alcohol consumption. Mainly alcohol is consumed in a home atmosphere, less commonly consumed in public places.

Limitations and strengths of the study. A limitation and a strength of this study is its focus on only one region of Ukraine - the Lviv region.

Practical/Social Value. The practical value of this research is to create a general panorama of the alcohol situation in the region and promoting the formation of an adequate anti-alcohol strategy for Lviv.

Originality/Conclusions. Reserves have been identified in prevention work, namely a reserve for anti-alcohol activity in communities, for its implementation by public organizations within the framework of integrated social services for the community.

Keywords: alcohol, patterns of alcohol consumption, anti-alcohol policy

The authors declare that they have no competing interests

Acknowledgement. This research was conducted during an internship at the Department of the Humanities Academy of Mining and Metallurgy in Krakow $(\mathrm{AGH})$ within the framework of the Prize named after I. Vygovsky. (AGH) as part of the Prize named after I. Vygovsky 


\section{References}

Zespół Fundacji Praesterno. (2018) Współpraca z Ukrainą w zakresie

rozwiązywania problemów alkoholowych w środowisku lokalnym

URL:/https://www.praesterno.pl/programy-biezace/wspolpraca-Z-ukraina-

w-zakresie-rozwiazywania-problemow-alkoholowych-w-srodowisku-

lokalnym/

RARHA (2017) Comparative monitoring of alcohol epidemiology across the EU

Baseline assessment and suggestions for future action. Synthesis report

URL:/http://www.rarha.eu/NewsEvents/LatestNews/Lists/LatestNews/Atta

chments/36/Comparative\%20monitoring\%20\%20of\%20alcohol\%20epide

miology\%20\%20across\%20the\%20EU\%20\%E2\%80\%93\%2027.02.pdf

WHO (2000) International guide for monitoring alcohol consumption and related harm

URL:/https://apps.who.int/iris/bitstream/handle/10665/66529/WHO MSD _MSB_00.4.pdf?sequence $=1$ \&isAllowed $=\mathrm{y}$ 


\section{ПРОБЛЕМА СПОЖИВАННЯ АЛКОГОЛЮ НА ЛЬВІВЩИНІ У СОЦІОЛОГІЧНОМУ ВИМІРІ (3А МАТЕРІАЛАМИ ЕМПІРИЧНОГО ДОСЛІДЖЕННЯ).}

Галина Герасим, Ольга Герус, Лариса Климанська, Віктор Савка (Львів), Януш Серославський

Національний університет «Львівська політехніка», Львів, Україна, Інститут психіатрії та неврології Варшава, Польща

1 Старший викладач кафедри соціології та соціальної роботи

2 Кандидат соціологічних наук, асистент кафедри соціології та соціальної роботи;

3 Доктор політичних наук, професор кафедри соціології та соціальної роботи;

4 Кандидат соціологічних наук, доцент кафедри соціології та соціальної роботи;

5 Координатор польської частини ESPAD, Інститут психіатрії та неврології, Варшава.

Загальну панораму алкогольної ситуації в країні або в регіоні дають не тільки дані соціальної, медичної і правової статистики, але і результати соціологічних досліджень. У травні 2019 року, з метою діагностики стану вживання психоактивних речовин у Львівській області, в рамках дослідницького проекту, реалізованогопольською Фундацією PRAESTERNO (Польща) і кафедрою соціології та соціальної роботи Національного університету «Львівська політехніка», при фінансуванні Державної агенції вирішення алкогольних проблем (Państwowa Agencja Rozwiązywania Problemów Alkoholowych ) PARPA (Польща, Варшава), проведено репрезентативне анкетне опитування 1200 респондентів віком від 18 років (800 у населених пунктах Львівської області та 400 у м.Львові). Польовий етап робіт виконувала львівська соціологічна агенція ФАМА при співпраці з кафедрою соціології та соціальної роботи Національного університету «Львівська політехніка». Дослідження здійснене за методологією та 3 використанням адаптованого до українських умов інструментарію європейських анкетних опитувань, реалізованих у 2016-2017 p.p. (RARHA 2017) . Тому отримані результати дають змогу не лише зафіксувати стан проблеми за апробованими у країнах Євросоюзу методиками, але й спостерігати іiі стан на Львівщині у порівнянні із ситуацією в країнах Європейського Союзу.

Оскільки метою статті є огляд лише частини проблем, піднятих у дослідженні, ми свідомо обмежимося лише тими, які стосуються вживання алкоголю та усвідомлення шкоди від цього жителями Львівщини. Саме 
такий предмет аналізу означено нами, зважаючи на значне місце алкоголю в культурі нинішнього українського суспільства та спроби виробників алкоголю, рекламних кампаній зміцнити його, збільшивши кількість споживачів алкогольних напоїв у різних суспільних групах. Однією із технологій, які використовуються в цьому процесі, $€$ «притінювання» негативних наслідків, чи повне їх заперечення у ряді пропагованих ними моделей «поміркованого і культурного» споживання алкоголю. Зважаючи на евристичні можливості соціології, ми також свідомо обмежуємося лише аналізом громадської думки про цей предмет і частково рівня усвідомлення його проблемності серед повнолітнього населення Львівщини.

Отримані результати свідчать про масштабність проблем, пов'язаних із вживанням алкоголю. Лише $15,3 \%$ опитаних заявили про те, що вони є абстинентами і повністю відмовилися від алкоголю. Але, на нашу думку, тут варта звернути увагу не лише на власне кількість тих, хто не вживає алкогольних напоїв. Важливо врахувати, що вони переважно належать до так званих груп із обмеженим соціальним потенціалом. Це особи похилого віку, а також ті, хто не працює чи має низькі доходи. Тому таке їх ставлення до вживання алкоголю можна назвати вимушеним (стан здоров'я, сприймання алкоголю як зайвої в умовах безгрошів'я розкоші тощо), а не свідомим вибором. Окрім того, рівень громадської активності, а отже і впливовості таких груп в суспільстві, також $є$, як правило, незначним, а тому їх важко розглядати як союзників у здійсненні антиалкогольних програм. Проте, така кількість абстинентів вплинула на середній рівень споживання населенням області: 5,37 літри чистого алкоголю на рік, при 6,35 літри в середньому для тих, хто споживає алкоголь. При тому слід врахувати, що визначення середнього рівня споживання алкоголю на основі лише опитувань дає значні похибки. На думку експертів, оцінка яких грунтується на врахуванні інформації і з інших джерел, йдеться орієнтовно про 12 літрів споживання алкоголю в рік в середньому на жителів області.

Отримані результати свідчать про, знову ж таки в середньому, низьку частоту пиття алкоголю, але при тому високий рівень його одноразового споживання (так звана інцидентна модель). В структурі алкогольних напоїв переважають так звані «міцні», на основі спирту. Споживання вина та пива $є$ 
істотно нижчим. При тому, споживання алкоголю відбувається, у більшості випадків, в домашніх умовах, а не у громадських місцях, що є побічним свідченням низького рівня доходів більшості суспільних груп, для яких проведення вільного часу у закладах громадського харчування не належить до поширених практик. Споживання алкоголю «за закритими дверима» також може бути свідченням чітко сформованої громадянської позиції алкоголь це зло і вживати його «на людях» не варта, оскільки потенційно це може бути причиною осуду з боку інших людей.

20,3\% опитаних заявили, що мають досвід частого одноразового надмірного вживання алкоголю. При тому 6,0\% визнали, що його результатом стало і самими ними уяснене надмірне пиття.

Як і у всіх європейських країнах, частота і кількість вживання алкоголю корелюється з віком та статтю: ці показники надмірного вживання завжди $є$ вищими для чоловіків, ніж для жінок. Найвищий середньорічний рівень споживання алкоголю нотується у віковій категорії 40-49 років, а найбільше розповсюдження явища одноразового надмірного пиття, найвищий середньорічний рівень споживання алкоголю та найвищий відсоток тих, хто споживає алкоголь надмірно, фіксується серед наймолодшої з респондентів вікової групи 18-29 років. При тому, у переважній більшості випадків, всі опитані розуміють ризики шкоди від вживання алкоголю як власне для себе, так і для оточуючих.

Найбільшим ризикам, а отже і шкоді для власного психофізичного та соціального здоров'я, для свого оточення, піддаються ті, хто споживає алкоголь надмірно. Під надмірним вживанням алкоголю розуміємо, відповідно до даних Всесві́тньої організа́ції охоро́ни здоро́в'я (WHO 2000) , вживання більше 40 грамів чистого алкоголю для чоловіків та 20 для жінок в день. Відповідно, це становить більше 16 літрів для чоловіків та 9 літрів для жінок споживання чистого алкоголю за рік. У досліджуваному масиві їхня кількість становить 9\% із опитаних загалом та $11 \%$ серед тих респондентів, хто заявив що не утримується від алкоголю. Відповідно, розподіл за статями: чоловіки $-14,8 \%$, а жінки - 3,9\%. Дещо більша кількість осіб, які надмірно вживають алкоголь, нотується у сільській місцевості - 10,8\%, далі за кількістю йдуть міста області $-8,6 \%$ та обласний центр $-7,1 \%$. Цікаво 
зазначити що навіть належність респондентів до особливої групи ризику: ті, хто управляє автомобілем, а отже потенційно несуть більшу загрозу і для себе, і для оточуючих, не стримує їх від надуживання алкоголю. Водіїв авто в цій групі є 13,9\% , а тих, хто не управляє автомобілем - 7\%.

Освіта, а отже і загальний культурний рівень, не впливають істотно на кількість тих, хто надмірно споживає алкоголь. Проте, таких осіб майже вдвічі більше серед працевлаштованих, ніж серед тих, хто не працює: відповідно 11 і 9,5\%\%. Очевидно, тут істотними чинниками є вік респондентів (у старших вікових групах-пенсіонерів рівень надмірного споживання алкоголю істотно нижчий, ніж у молодших), та наявність вищих доходів, які й уможливлюють більший рівень пияцтва. При тому, активніше громадське життя в умовах достатньо толерантного ставлення у вітчизняному соціокультурному середовищі до вживання алкоголю, тут також відіграє свою негативну роль.

Істотним чинником, який впливає на надмірне пиття, $є$ ставлення до релігії: найнижчим тут є відсоток віруючих і практикуючих релігійний культ - 5,8\%, а найвищий відсоток (18\% ) становлять ті, хто вважає себе невіруючими. Чинник конфесійної приналежності тут не відіграє істотної ролі, і тому серед вірних всіх конфесій кількість тих, хто вживає алкоголь надмірно, є практично одинаковим. Дещо більша кількість греко-католиків $(8,7 \%)$ у порівнянні з православними $(7,9 \%)$ може бути пояснена загалом меншою кількістю православних серед населення Львівщини.

Про поширеність вживання алкоголю на Львівщині свідчить і той факт, що 59,1\% респондентів заявили: до кола їхніх близьких належать люди, які систематично, чи хоча б інколи, вживають алкоголь надмірно. 3 них 36,6\% є приятелями, чи знайомими, 27,5\% - сусіди, 20,7\% - співробітники, чи товариші по навчанню і праці. Серед рідних такими є $8,9 \%$, а в родині $6,9 \%$.

При тому, оцінюючи рівень надмірного вживання алкоголю, слід зауважити, що використання в опитуванні тесту RAPS дозволяє оцінити кількість тих, хто надуживає алкоголем, не у 9\%, як заявили респонденти, а орієнтовно у 17,5\%. Отже, і решта вище наведених даних вимагають відповідної корекції в сторону збільшення. 
Для опрацювання варіантів реакції суспільства на надмірне вживання алкоголю, протидії цьому важливо знати, наскільки респонденти усвідомлюють шкоду такої поведінки для себе та інших.

Передусім такого роду шкоди стосуються неприйнятної для опитаних поведінки осіб, які були нетверезими. Майже 40\% респондентів були свідками непристойної поведінки таких осіб, 25,3\% - різного роду образ, 23,6\% заявили про незручності від порушення п'яними нічної тиші, а 12,\% про загрозу від нетверезих у публічних місцях, 6,2\% про ризик зазнати тілесних образ, а 1,4\% заявили про можливість дорожніх пригод, спровокованих п'яними. Кількість тих, хто сам відчув шкоду від таких дій 3 боку нетверезих, $є$ істотно нижчою. На першому місці (13,2\%) тут певні втрати і незручності респондентів від непристойної поведінки нетверезих, на другому місці (9,9\%) спроби провокування респондентів на різного роду сутички, чи і участь у них, а 8,7\% опитаних самі відчули незручності від порушень нічної тиші. Загалом серед респондентів зафіксовано 40,5\% осіб, які заявили про якусь із проблем, спровокованих нетверезими.

Особливою групою потенційних жертв надмірного пиття батьками та рідними є неповнолітні, оскільки такого роду досвід може мати трагічні наслідки для них навіть пізніше, у дорослому житті. В цілому по області $21,2 \%$ респондентів ствердили, що мешкали, будучи дитиною, чи неповнолітнім, разом з кимось, хто пив надмірно. Серед таких осіб 15,4\% це батьки та 7,6\% хтось інший із близьких родичів, хто належав до їхньої родини та проживав разом із ними. 13,4\% 3 них ставали жертвами зневажливої поведінки з боку таких осіб, а 1,4\% відчували образи дуже часто. Іншими варіантами зазначеної шкоди з боку близьких, які надмірно пили, були: залишення дітей без опіки у загрозливих ситуаціях - від 0,6\% відповідей «дуже часто» до 6,9\% - «інколи» та «рідко коли»; фізичного насильства, хоч би епізодично, зазнали дещо більше $8 \%$ осіб, а майже $12 \%$ були свідками насильства в родині.

Співставлення рівня розповсюдженості вживання алкоголю 3 результатами досліджень за цією ж методикою, проведених у 19 країнах Євросоюзу дозволяє зробити висновок про те, що Львівщина займає середні позиції за більшістю показників і є близькою за ними до сусідньої Польщі. 
Вирізняє Львівщину на фоні європейських країн високий рівень тих, хто заявив про шкоду для них самих і суспільства від надмірного вживання спиртних напоїв. Це, на наш погляд, свідчить про наявні резерви у профілактичній роботі. Висловлене значною кількістю респондентів негативне ставлення до надмірного вживання алкоголю та розуміння алкоголізації населення як проблеми, дозволяє бачити резерв для антиалкогольної активності саме в громадах, для iї провадження громадськими організаціями та, відповідно, методами соціальної роботи. Цілком очевидно що менш формалізовані та ближчі до об’єктів впливу (i, принаймні частково, 3 їхнім залученням) форми протидії поширенню алкоголю є набагато результативнішими у порівнянні з формалізованими, до яких схильні державні структури. Проте, і роль державних органів тут також $є$ надзвичайно важливою, оскільки, по-перше на нинішній час саме вони, а не структури громадянського суспільства, $є$ більш організованими та впливовими, по-друге, навіть за умов нарощення дієздатності громадських організацій, розширення можливостей їхнього впливу на проблему, власне за державними органами може залишатися координуюча функція. В зв'язку 3 цим опрацювання обласної програми протидії проблемам, пов'язаним із алкоголізмом, яка б об’єднувала зусилля як владних, так і громадських структур, є актуальним завданням. 